\title{
Political Reform in Brazil and Contradictions in the Legal Understanding of Party Loyalty
}

\author{
André Garcia Xerez Silva \\ Federal University of Ceará, Fortaleza, Brazil \\ University of São Paulo, São Paulo, Brazil
}

\begin{abstract}
The Superior Electoral Court anticipated the political reform with the creation of party loyalty, reproduced in infra constitutional legislation by Law $\mathrm{n}^{\circ}$. 13.165/2015. The change in the electoral system allows imagine the foundation of a State Parties in Brazilian democracy. Although most constitutions incorporate the virtual mandate idea, or representative, according thought of Burke and Sieyes, the democratic legitimacy requires control mechanisms and accountability of representatives to the population, including legal. It takes up to the imperative mandate, not in Rousseauian molds, but tied to party guidelines, founding party mandates. The ownership of the mandate by the political party moves towards the strengthening of key players who are partisan associations in the electoral process. On the other hand, it is not obvious that political parties meet the necessary conditions for the establishment of an imperative mandate tied to party deliberations, since patent oligarchic and bureaucratic character of much of them, whose process of deliberation and choice of leaders and political positions do not require internal democracy. This reflection induces the political and party system to wonder if the role they playing in democracy helps to combat political inequality or strength it, by analyzing the dynamics of party migration in Brazil.
\end{abstract}

Keywords: political reform, contradictions, Party Loyalty

\section{Historical of Legislative Process}

The political party loyalty was disciplined in the Law number $13.165 / 2015$, a regulatory statute which is a result of the intense debate concerning "Political Reform" in the National Congress's agenda throughout 2015. Although it does not substantially alter the guidelines of the electoral procedure, considerable changes were made regarding the current topic. It is inevitable not to think that in order to establish a legal conception of political party loyalty, there has to be an ideological alignment between the parties and the ideals supported by its affiliates, where voter's interests will be represented to achieve popular sovereignty.

The endless amount of a variety of legislative proposals designated to alter the electoral system and the functioning of political institutions, surrounded by a wide political reform issue, has always made the development of a consensus more difficult concerning its approval. The House of Representatives and the Senate joined forces for the voting and the approval of the issues in question in both legislative houses and for its publishing until October 2, 2015, confirming efforts within the necessary period for the 2016 elections.

André Garcia Xerez Silva, master of Law, Federal University of Ceará; Ph.D. candidate, Public Law Department, University of São Paulo. 
Even though each of the Legislative organs has created their own Political Reform Commission, the idea was to conduct the procedure of the proposals to accelerate the political reform debate and make it more efficient.

The president of the Federal Senate, Renan Calheiros, designated on June 17th, 2015 through act number $12 / 2015$, a Special Committee with the purpose of systematizing the propositions concerning the Political Reform, initially establishing a deadline for June 30th to present the report, which was extended to October 3rd through Act number 15/2015.

The debate was initiated in the Committee and proposition minutes were presented by the rapporteur, Senator Romero Jucá. On August 5th, 2015, it was agreed in the Commission, together with the rapporteur of the Political Reform in the House of Representatives, Rodrigo Maia, to put into debate in the Federal Senate the House of Representatives proposed bill number 75/2015 ( $n^{0} 5.735$ of 2013, in the originating House), from the authorship of the representative Ilário Marques, that joins all infra-constitutional subjects in a ${ }^{1}$ single proposed bill, in order to accelerate the procedure without compromising what was deliberated by the Senate Committee.

In the proposed bill number 75/2015, which alters the Laws numbers 9.504, of September 30th, 1997, 9.096 of September 19th, 1995 and the Law 4.737 of June 15th, 1965-Electoral Code, changing the political-electoral institutions, it was stated that the proposition concerning party loyalty with the inclusion of item 22-A in the Law number 9.096/99, transcribed below, has used the written text of the Superior Electoral Court number 22.610/2007 regarding the hypothesis of just cause for the party exclusion.

Article 22-A. The holder of the elective mandate who decouples the party in which he/she was elected by will lose the mandate, unless if the decoupling occurs: (I) to be affiliated to a new party, in the thirty consecutive days to the registration date in the legend in the Superior Electoral Court; (II) due to merger or incorporation of their original party to another, in the thirty following days to the registration of the party alteration that occurred; (III) due to substantial change or deviation reaffirmed in the program of the original party; (IV) for serious personal discrimination.

The voting of the report presented by the rapporteur through the legal recommendation number 637/2015 was concluded on August 25th in the Committee meeting. On September 2nd the complementary bill number $75 / 2015$ was voted in the plenary, resulting in the recommendation number 682 , of 2015 , with the text of the Substitutive approved by the Senate in the bill in which the inclusion of the item 22-A was confirmed to the Law number 9.096/96.

Taken back to the House of Representatives, through the approval number 1243 of September 8th, 2015, the subject was voted in a single shift, in the Extraordinary Deliberative Session on September 9th, 2015, where the final presentation of the bill number 5.735/2014 definitively consigned the following terms regarding the discipline of party loyalty:

Article 22-A: holder who decouples its party without just cause will lose elective mandate. Single paragraph. Just cause is considered for party decoupling in the following hypothesis: (I) substantial change or deviation of party program; (II) serious personal political discrimination; (III) changing of party accomplished during the period of thirty days which anticipate the deadline of affiliation demanded by Law to run in elections, major or proportional, in the end of the current mandate. (Law number 9.096/95)

The Board did not reproduce ipsiliterris in the terms of the Superior Electoral Court Resolution number 22.610 about party loyalty legal framework, going against the Federal Senate's approval. The just cause

\footnotetext{
1 Article 1: The interested political party may request to the Electoral Justice the decree for loss of elective position due to party disaffiliation without just cause. It isconsidered Just cause when: (I) partyincorporationor merge; (II) Creationof a new party; (III) Substancial changeordeviationofpartyprogram; (IV) seriouspersonaldiscrimination.
} 
hypothesis compatible to substantial change or reaffirmed deviation in the party's program and in case of serious personal discrimination remained, however, those related to the creation of a new party and to the merger or incorporation of parties were extinct. Nevertheless, an infamous "window" was created in the infra-constitutional scope through a new just cause hypothesis which gives the representative the right to change parties within the 30 days which precede the affiliation deadline by law to dispute major or proportional pleading.

Finally, the project was sent for sanction or veto form the Republic Presidency on September 10th, 2015 through Message number 28/2015, being entirely sanctioned, the text of the referred legal instruments on September 29th, 2015, resulting in Law number 13.165/2015.

The recent decision from the Federal Supreme Court on the Declaratory Action of Unconstitutionality number 5081, gave injunctive relief to mandate loss due party unfaithfulness to representatives elected by the major system. This article is restricted to investigate its impact for the ones elected by the proportional system.

\section{Representativeness in Democracy: Categories of Political Mandate}

Many academic papers have contributed to the concept of popular representativeness in current democracies, where we can highlight the positioning of Rousseau and Edmund Burke.

Before continuing, however, it is important to realize that although the representative characteristic of sovereignty as a role model government is defended, this was initiated as a necessity due to community growth, which would not make it possible for everyone to participate in public businesses, as Stuart Mill (2006, p. 65) and Jacques Rancière (2014) defended "representativeness was never a system created to soften the impact of population growth" (p. 69).

In its origin, representativeness is the opposite of democracy once it represents an oligarchic form of legitimating the status quo in order for the elite to truly fulfill, in the name of the people, the power which is an obligation. That's why Jacques Rancière (2014) supports that representative democracy "may seem as a pleonasm, but it was first an oxymoron" (p. 70). This phenomenon was not totally relegated to the past century of the bourgeois. While studying the legitimacy of political power which great part of the constitutions attribute for themselves through "the power of the people", Friederich Müller (2011) observed nowadays an invocation of the people as an "icon" in the sense that "a heterogeneous population is unified for the benefit of the privileged and establishment occupants, it is anointed as "people" and pretended to be-through the monopoly of language and of the definition in the hands of dominating group(s) - constituent and constitution keeper" (p. 64).

This urging does not focus on the belief of a returning right democracy as the only possibility of democracy once it constitutes a current obstacle to its practice, even though population growth has not justified, in a first moment, the birth of representativeness. Actually, what is needed is the understanding of democracy as "struggles against the natural logic of the electoral system, which transforms representativeness in a representativeness of the dominating interests and the election in a mechanism destined to consent: official candidature, electoral fraud, candidature monopoly" (Rancière, 2014, p. 72).

With this knowledge, it is important to discuss the concepts of imperative mandate, led through the considerations of Jean-Jacques Rousseau, and the virtual mandate through the eyes of Edmund Burke.

The premise that sovereignty is inalienable is supported by Rousseau $(2007$, p. 36) "if sovereignty is not more than the exercise of the majority's will, it can never alienate itself (...)". Corollary of inalienability, is the 
indivisibility of sovereignty "either the will is general or not; either it is of the full voting or of just a part of it" (Rousseau, 2007, p. 37).

Therefore, the idea of an imperative mandate is set, which is connected through the direct link between the voters and the elected, Who must act as real commissioners to the people's will if it is impossible to attend general will. For Rousseau (2007) "(...) the deputy of the people are not and cannot even be, their own representatives; they are their commissioners, and cannot conclude decisively. It is null and it is not a law that in which the people do not rectify" (p. 87). Therefore, political representation can never be mediated by third parties, under penalty of annulment once Rousseau's philosophy states the misrepresentation of popular sovereignty, which is inalienable and indivisible.

From another perspective, Edmund Burke (2004) goes against imperative representation, supporting that:

The parliament is not a congress of ambassadors which defend distinct and hostile interests [...] but a deliberative assembly of a nation, with one interest: the interest of the whole, where what must prevail is not the local interests and prejudices, but the well being which results in the general reason of all. (p. 29)

The virtual mandate, or representative mandate, is founded in the lights of the Burke's liberalism and understands representation aside from the immediate interests of the population, or part of it, making a commitment to defend, above all, the interest of a nation. This juridical conception is adopted by most of the constitutions, as Monica Caggiano (2004, pp. 13-14) points out; The Constitution of France establishes in its article 27 that, "all imperative mandate are null", as well as it is established in the Spanish Constitution of 1978 and in the Romanian Constitution of 1991. This is justified mainly by the influence of the thesis on national sovereignty of Abade Siéyès, in which a mandate is conceived belonging to a nation (Caggiano, 2014, p. 14).

Nowadays, the political representative mandate is severely criticized mainly for the lack of control mechanisms upon the represented when making public decisions, which accentuates, according to Orides Mezzaroba (2004, p. 77) the "oligarchic character assumed by representative organs". The critique finds grounds in Friederich Müller's philosophy (2011, p. 57) when it states that the fact that the power of the State comes from the people must be understood "as executed through the people in an accountability regime accomplished by them". This premise is not metaphysical, but normative, that's why Müller (2011) defends that "it cannot remain as fiction, but it must have the power to result $\mathrm{n}$ sensitive sanctions in reality, having necessarily by its side a democratic promise in its active variation", an important observation about a more specific reflection which discusses mandate loss by party unfaithfulness as a control mechanism of the people's representatives (p. 57).

Mezzaroba (2004, p. 78) adds to the categories of imperative and virtual or representative mandate, the party mandate, driven by the Kelsen's formulation of State Party in answer to the demands which were not attended by the representative democracy.

The position assumed by political parties in the constitutional sphere would make them responsible for "putting together coincidental individual will and interpose them in the state sphere" (Mezzaroba, 2004, p. 78). In this political mandate model, the people would still rule themselves, even if indirectly, as the citizens would be responsible for establishing governmental guidelines through its articulation in the party scope instead of elected representatives with power to decide in their name.

Therefore, in the dynamics of the State of Party, the aspect of representative mandate disappears, strengthening an imperative character, not linked to the voter's individual will. The link is regarding the party 
determinations, that, for Mezzaroba (2004, p. 78), what matters is "the party loyalty becomes a fundamental prerequisite for the party mechanism and, consequently, for the existence of a Sate of Parties".

In the same way, Bruno Araripe (2014) supports the overcoming of the imperative model "based on the divine or aristocratic figure conceived in the direct relationship between monarchs and subjects or elected and voters" and the virtual mandate, for a new positioning in which "there's investment in the imperative mandate linked to the ideology of the party group" (pp. 31-32).

Having explained the kinds an tendencies of a political mandate which mediate popular representation, it is important to analyze repercussion in the democratic theory of the effects of party loyalty conceived by Law number 13.165/2015 in the representative system outlined by the Federal Constitution of 1988.

\section{Institutional Contradictions of Party Loyalty With the Reduction of Minimum Affiliation Time: Does the Power Emanate From the People or Political Parties?}

Monica Caggiano (2004) reveals that, despite the rising of the political parties from the second half of the twentieth century, the Brazilian Constitution of 1988 establishes the condition of a congressman as the people's representative even if they depend on party affiliation as a eligibility condition (article $14, \S 3^{\circ}, \mathrm{V}, \mathrm{CF} / 88$ ) (p. 14). This author has already defended (Xerez, 2012, p. 214) the importance of the strengthening and plurality of the political parties in order to show the complexity and inequalities of the country, ratifying the idea of Party States as a path for the improvement of the democratic regime.

The current problem is to question whether the constitutional text and the established political-electoral system are compatible with the logic of State Parties. Mezzaroba (2004, p. 78) expresses that, in the Kelsen model, those are conditions for a party to have as key piece of the political structure in which "it will be purified of any addiction, structured internally in a democratic form - the baselines choose their leaders, without any bureaucratic trace and free from corruption - public and transparently financed". Would this be the reality of the Brazilian political parties? Evidence shows that this is not what goes on in the political logic of the country.

The difficulty to actually see political parties in the terms of Kelsen is not restricted to the Brazilian scenario. The French thinker Maurice Duverder (1980) highlights that "the direction of the parties tends to naturally assume an oligarchic form", a symptom that is applied "both to the autocratic leaders such as to the democratic leaders" (p. 188). He argues that, paradoxically, instead of the internal elections impeding the birth of oligarchies, they actually seem to benefit them.

The German philosopher Robert Michels (1982) has a similar analysis when he verifies that "the supreme leaders of an eminent democratic party, named by indirect vote extend until the end of their existences the powers which were given to them once" (p. 64). Election transforms itself in a simple formality when facing the irremovable and inviolable leaders, whose responsibilities "surpass the average time of ministry responsibilities in the monarchic States" (Michels, 1982, p. 64).

Kelsen's proposal concerning internal democracy choosing their leaders in political parties is almost a utopia with the reality studied by the previously mentioned authors. Duverger (1980, p. 192) exposes the bureaucratic character of military regimentation to occupy leading positions in the party, highly controlled by their party loyalty, arising "an authentic oligarchy which possesses power and maintains and passes it on through co-option". Michels (1982) contemplates the situation in similar terms:

As the leaders pull away from the masses, they show themselves more willing to occupy empty spaces which are produced by their actions and not through popular election, but by co-option; increasing their permanency and creating, by 
their own initiative, whenever possible, new positions. The leaders tend to isolate themselves and form a kind of cartel within a wall that can only be transposed by the ones that please them. (p. 64)

It is impacting to realize that this quote reveals the existence of party "leaders", making it evident an association as property of an individual who appropriates himself of it. The cartel formation in parties is a reality of simple empirical observation. Having the knowledge that the Brazilian party structure is not dissociated from the referred diagnosis, it is necessary to reflect about its alignment with the presumptions of a State Party.

The requirements indicated by Kelsen are far from what is observed in the current dynamic party scenario, making it questionable the postulate application caused from the idea of political parties developing the role of joining collective interests, which are in harmony with its internal structure.

The organic weakness of the parties and the permanent oligarchic process and bureaucratic characteristic of its structure reflect Friedrich Müller's opinion about who are the represented people in the State sphere. While analyzing the German Constitution, which attributes to the political parties co-option when forming the people's will, he questions:

Who would make this co-option legitimate - the people or just the party members or even, with reference to theses lasts, their active members, not counting the inactive ones, which are only numbers-or even more, only the installed oligarchic leaderships (or single leaders)?

We can observe the sarcasm of collocations anticipated by the answer to the questioning. The ability of the associations to represent with legitimacy the people's interest, even if not directly, as Mezzaroba proposed, conflicts with the organization and structure of the parties, which impede the construction of a collective and democratic will. We can observe in Brazil, due to the constitutional command which guarantees autonomy to the parties, that few parties are concerned about organizing serious elections for their leaders. Most parties don't even deliberate or consult members; the most they do is give symbolic processes to the elected leaders the appearance of an election. Due to this reason, we can affirm that political parties have owners and that they are highly profitable businesses with a true business nature, mainly because of the market installed to buy and sell television time, which is paid with public money, and they do it according to the electoral legislation.

This sociological phenomenon, which must also be studied through a juridical perception, discusses the role of the electoral systems in the structure formation of the parties. It is essential to observe the effects of proportional vote in open list institutionalized in Brazil for the Legislative member's choice.

Jairo Nicolau (2007) expresses that "aside from the motivation for the campaigns to be centered in the candidate, the open list affects parties by stimulating competition between members of a same party" (p. 106). The filling of the positions available to the party for the satisfaction of electoral coefficient is due to the major classification of the candidate's votes. The dispute is brought mainly to the internal scope of the own party, once every candidate has the freedom to gather votes specifically for themselves, even though the possibility of the voter to vote exclusively because of the party exists. The freedom to gather resources directly for their own campaign is also something that certainly individualizes the competition for votes because, although it is possible that the party donates money for candidates, the accountability reveals a bigger capital flow due to private donations, which must be mitigated with the possible sealing of resource donation by legal entities.

Another consequence of the open list proportional model investigated by Jairo Nicolau (2007) is the emphasis given to the representative to fulfill specific demands as a measure of electoral success, based on a 
relationship of nurturing particular interests, crony projects and the defense of the interests of the electoral district. A research made with Brazilian congressmen showed the central importance of a connection with city life through constant visits to cities where they were voted, the release of budget amendments and the intermediation of plea from the mayors and local leaderships, reinforcing even more the person-based character which is involved in the mandate (p. 106).

To confirm what has been exposed in statistical term, a research made by IUPERJ-2002 showed that 92\% of the voters responded that the candidate was the most important in determining their vote, while only four percent affirmed that they considered the party legend as the most important (Nicolau, 2007, p. 109). Two months after the plea, $46 \%$ of the voters didn't remember or were not able to answer the name of the party which they had voted for. In addition, a research made by IBOPE in the middle of 2013 revealed that the institution that Brazilian trust the least are the political parties.

When Law number 13.165/2015, modified article $9^{\circ}$ da Lei $n^{\circ} .9 .504 / 97$ to reduce affiliation time from one year to six months, it weakens the relation of identity between the affiliated and the association, which must be the keynote that justifies mandate loss of those who leave the party disregarding the legal hypothesis of just cause. When the procedural protocol in the Senate of the bill that resulted in an alteration in the legislation, it was stated in the minute 3 presented by the rapporteur in the Political Reform Committee the following argument:

The existing deadline is not consistent with the electoral calendar. When October is near in the year before the plea, the voter that wishes to run for a nominating position must choose a party without knowing how that party will position itself in the alliances which will be formed before the dispute. Usually, only throughout the election year possible colligations and pre candidates start defining themselves around the alliances that will be formed.

Although the deadline for candidate affiliation did not prosper in the Senate, we can observe that the reasons for such comes from the premise that "the voter who wishes to run for an elective position must choose a party without having the slightest perspective of how that party will position itself in the alliances that will be formed in the dispute", and recognizes, even if indirectly, an ideological weakness of the parties to position themselves in succeeding elections which would make citizens hostage at the moment of the party choice they intend to run for.

This logic brings the problem to surface and proposes a measure to actually deepen it, because when admitting randomness in the formation of alliances in the plea dispute, the voter could wait for a greater definition in politics from the parties for only then joining one of them, which attracts the paradox identified by the President of the Political Reform Committee, Senator TiãoViana (PT), who questioned: "what reason would we have to shorten the deadline for party affiliation if we want to strengthen party loyalty?"

It is not convincing to contemplate that the reduction of the minimum affiliation time would stimulate a greater participation from the citizens in the electoral process that faces a political crisis scenario and democratic apathy. According to data from the Superior Electoral Court, there is a recent decrease in the amount of affiliation when compared to the months of December, 2014 (15. 320.151) and September of 2015 (12.131.855), after a period of permanent increase from October, 2007 (11.759.699) until December, 2014. The information from the Electoral Justice allow the statistics of affiliated people to be accessed; from October 2002 (11.131.135), the moment where there was a boost of affiliations, until July of 2004 (11.794.247) and following are repeated reductions until October of 2007, when there was an affiliation growth in the parties. 
During all the analyzed period, the demand of one year prevailed as a condition for eligibility, although there were moments of an increase or decrease in the number of affiliations that cannot be directed related to the current legislation. Therefore, the experienced political context is the key factor for civil engagement. Even if there is a recent reduction in the amount of affiliations, the same phenomenon was also observed in other moments, without resulting in the necessity of modifying the minimum time for party affiliation as a candidate. The idea was to have a growth in affiliations between the years of 2007 and 2014.

The measure to benefit the improvement of the democratic environment is not detected, even if there was a possibility of facilitating the candidature phenomenon by the political parties, the direct relation between legislation altering and amount of affiliation to party associations is not perceived.

Reducing the necessary interregnum of party life to run in the elections is ideal for party loyalty. Stimulating the distance between the affiliated and the political party, although it doesn't justify in practice the juridical prominence given to it, depends on the ideological alignment between its guidelines and its representatives as an assumption for mandate loss in cases of disaffiliations without just cause.

That's why topics like the proportional model with open list, campaign financing, party creation procedures, election threshold, and minimum affiliation time, among others, are aspects which contribute to the formation of the profile that is intended to be established in the political parties and can't be unassociated with the understanding of party loyalty.

The migration between political parties during a mandate is rejected due to the fact that it constitutes a rupture in popular will, weakening the party, which has the monopoly of the candidatures and the leading role of the electoral process and whose votes, individual or collective, are the parameter for the determining of the electoral coefficient, which allows the mandate to the candidate in the Legislative. In Brazil, however, Desposato (2007, p. 139) points out that "this phenomenon is less problematic than it may seem at first sight, for many reasons".

When analyzing the behavioral dynamics of party tourism, Desposato (2007) observes that "moving from one party to another with similar ideological position, but with other disagreements (for example, the candidate who supports the governor), reflects, most of the times, the internal policy of coalitions, which is the reason why it does not go against the ideological preferences nor it is a representation threat" (p. 139). This is the central point of this paper.

Party oligarchy and the electoral system, which both reinforce candidate personalism as a determining voting factor, weaken the existence of juridical loyalty in the current reality of the political parties. Even if the resolution number 22.610 in the Superior Electoral Court represented an advance in the strengthening of political associations, it is necessary to observe that this boost is expressed in the juridical sphere. In other words, a juridical party loyalty was created, but an ideological party loyalty was not institutionalized. As we have seen, the aspects of the electoral system continue to privilege the individual figure of the candidate other than the political party and this matter is worsening with the reduction of minimum affiliation time.

From this gap between the juridical and the political, a dangerous threat to the democratic regime is born. With the pretext of moralizing the electoral system, party loyalty, which is now in article 22-A of the Law number 9.096/95, armed the oligarchic parties with legal instrument capable of resulting in the rupture in representativeness once it takes to itself the votes with a personalism characteristic given to the voters to their candidates. From the idealistic perspective of Kelsen about State Parties, Mezzaroba would be right in defending the existence of a juridical loyalty to the political parties. 
The political reform initiated by the Superior Electoral Court and now reproduced in the infra-constitutional legislation is serving a purpose which goes against what was firstly intended for. The fragile ideological consistency of the parties that either motivates great part of the party migrations or determines the votes has been transformed in a tool of threat and cooption, strengthening the spurious functioning logic of most of the parties.

There is no sense in creating a juridical procedure of party unfaithfulness without instituting mechanisms which benefit the ideology of party loyalty, which is harmed with the decrease of the affiliation deadline for candidatures. Until this becomes a reality, which demands the discussion of several issues that are influenced by the electoral process, the juridical possibility of transferring the mandate to the party by the "unfaithful" disaffiliation benefits the physiological behavior from most parties and punishes congressmen so that they don't surrender to the autocratic plan from the leader of the association, even if their political behavior does not go against the interest of the population that elected them.

Possibly to protect those who feel threatened by this situation, the Law number 13.165/2015 created a permanent "window" for party mandate disaffiliation upon the inclusion of a new just cause hypothesis which consists in the "changing party during the period of thirty days prior to the affiliation deadline demanded by law to run the election, major or proportional, at the end of the current mandate", according to text III of the article 22-A of Law 9.096/95.

The system tries to conciliate the contradictions that involve the existence of party loyalty lacking ideological alignment between representatives and parties, without correcting the root of the problem. The so criticized permanent exchange of politicians between parties has been institutionalized. A citizen cannot have their full basic right to eligibility while subjected to the "owners" of the parties, but the "window" presents itself merely as a way to escape the system which is mistaken in its conception.

Despite of the party defector introducing a "feeling of insecurity and uncertainty for the voter", it results in the "violation of trust that the voter manifested" (Caggiano, 2008, p. 251), article 45 of the Federal Constitution reveals that "the congressmen may be judged by their acting only by the people, or in other words, their conduct will be appreciated if they attend or do not attend the demand of responsiveness". Caggiano (2008) highlights the need of a reforming power to "indicate the limits of the congress mandate" (p. 252).

Therefore, to answer the proposed question in this article, popular sovereignty cannot rest in party guidelines forged by structural oligarchic tendencies, organization and functioning of political parties, for it will be destroyed by the uncritical concept of party loyalty shaped by Resolution number 22.610 of the Superior Electoral Court, incorporated by the Law number 13.165/2015. Daring to disagree with Mezzaroba, party loyalty should not be a prerequisite for the existence of a State Party, but a consequence.

\section{Conclusions}

The Superior Electoral Court anticipated the political reform through the edition of the Resolution number 22.610, partially reproduced in the infra-constitutional legislation, through Law number 13.165/2015. This punctual, but deep alteration in the electoral system provides imagining the foundation of a State Party in the Brazilian Democracy.

Although most of the constitutions incorporate the idea of virtual or representative mandate, according to Burke and Siéyès, the democratic legitimacy imposes a control mechanism of accountability of the representatives before the population, including juridical. This resumes itself to imperativeness in the mandate, 
not in Rousseau's models, but linked to the party guidelines, establishing party mandates.

The juridical substrate which attributes mandate entitlement to the political party instead of the candidate goes in the direction of strengthening important actors, which are the party associations in the electoral process, above all by the monopoly of candidatures. On the other hand, it is not evident that the parties attend the necessary conditions for establishing an imperative mandate linked to the party deliberations once there is an oligarchic and bureaucratic character of most parties before the Superior Electoral Court, whose processes of deliberation, leader choice and political positioning do not have any traces of internal democracy.

Aside from this, the proportional system with open list, the campaign financing regime and the reduction of minimum affiliation time to dispute plea weaken the parties and enhance the personal figure of the candidate instead of convincing voters, which allow the understanding that the associations are still not as important as a channel instrument of popular sovereignty. There is no doubt, however, that the contemporary constitutionalism points to the strengthening of political parties as a necessary step for the improvement of the democratic regime.

However, before instituting a juridical loyalty in the system, it is necessary the existence of an ideological political loyalty in order not to alter the dynamics in the party functioning. The juridical tool available for the parties to review the mandate of those who disaffiliated without just cause gives even more strength for the party "leader" to practice anti democratic actions which weaken the party structure as well as it provokes a rupture in popular sovereignty.

Jacques-Rancière's understanding of democracy as a fighting process against the natural logic of the electoral system of dominant interest representation and statement of the public character of relations, institutions and spaces considered private, actually shoes that if party loyalty is not followed by other modifications in the electoral system, we will have lost a battle in this fight. Cláudio Lembo (2012) wrote that the party shackles, the violators of will autonomy, forge "political slaves" in what we call a democracy (p. 243).

\section{References}

Araripe, B. C. B. (2014). The Brazilian political party: democracy and its consolidation after 1988. $2014.128 \mathrm{f}$. Dissertation (Constitutional Law Master) — Law Postgraduation Program of Fortaleza University, Fortaleza University, Fortaleza.

Burke, E. (2004). Speech to Bristol voters. In F. C. Weffort (Ed.), The political classics (10th ed.) (Vol. 2, pp. 27-45). São Paulo: Ática.

Caggiano, M. H. S. (2004). Parlamentary and electoral law. Barueri: Manole.

Caggiano, M. H. S. (2008). The phenomenology of immigrants in the electoral political scenario. In C. Lembo \& M. H. S. Caggiano (Ed.), The vote in Americas (pp. 219-254). São Paulo: Cepes.

Caggiano, M. H. S. (2014). Democracy x constitucionalism: a driftingship? Postgraduation Law Notebook: Studies and work documents, 1, 5-23.

Desposato, S. (2007). Brazilian political reform: What need to be fixed, what doesn't and what to do. In J. Nicolau \& T. J. Power (Ed.), Representativeness institutions in Brazil: Balance and reform (pp. 123- 153). Belo Horizonte: UFMG.

Duverger, M. (1980). The political parties. Tradution of Cristiano Monteiro Oiticica (2nd. ed.). Brasília: UnB.

IBOPE. (2014). Retrieved May 30, from

http://www.ibope.com.br/ptbr/noticias/paginas/cai-a-confianca-dos-brasileiros-nas-instituicoes-.aspx

Lembo, C. (2012). Daily visions. Barueri: Manole.

Mill, S. (2006). The representative government. Tradution of Débora Ginza e Rita de Cássia Gondim. São Paulo: Escala.

Mezzaroba, O. (2004). Brazilian party law introduction (2nd ed.) Rio de Janeiro: Lumen Juris.

Michels, R. (1982). Political party sociology. Tradução de Arthur Chaudon. Brasília: UNB.

Müller, F. (2011). Who is the people?: The fundamental democracy question. Tradution of Peter Naumann (6th ed.) São Paulo: 
Courts Journal.

Nicolau, J. (2007). The open list system in Brasil. In J. Nicolau \& T. J. Power (Eds), Representativeness Institutions in Brazil: Balance and reform (pp. 97-122). Belo Horizonte: UFMG.

Rancière, J. (2014). The hatred of democracy. Tradutionof Mariana Echalar. São Paulo: Boitempo.

Rousseau, J. J. (2007). Social Contract: Or political law principles. Tradution of Pietro Nasseti. São Paulo: Martin Claret.

Xerez, A. G. S. (2012). The ownership of elective mandate: Political party or party coalition? In C. M. Mariano \& M. M. B. Lima

(Eds.), The Supreme Court of Brazil and the hard cases (pp. 207-224). Florianópolis: Conceito. 